\title{
PENGENDALIAN DIRI REMAJA MELALUI KEGIATAN PENCAK SILAT SISWA DI MTsN 6 PONROGO
}

\author{
Hamid Mahendrat Kusworo \\ Fakultas Ushuluddin, Adab dan Dakwah IAIN Ponorogo \\ kadalmesir@gmail.com
}

\begin{abstract}
The first purpose of this study is to determine the form of self-control in pencak silat. Second, to find out the form of increasing self-control of MTsN 6 Ponorogo students. The formulation of the problem in this study is the first, how is the selfcontrol of adolescents who participate in pencak silat activities. Second, how are the forms of increasing adolescent self-control through pencak silat activities at MTsN 6 Ponorogo. To answer these problems, this study uses a descriptive type of research with a qualitative approach. Researchers get data from interviews, observations and documentation. The results showed that the form of increasing self-control of MTSN 6 Ponorogo students was in accordance with the theory presented by the researcher. First, being able to control emotions. Second, being able to adapt, this adjustment can mean changing oneself according to environmental conditions. Students who follow pencak silat can adjust to where they are. Third, the achievements obtained in pencak silat will develop students' creativity. Through the problems faced will automatically make students think to find a way out. Student creativity will make the atmosphere comfortable and conducive. There was an increase in self-control in students who participated in pencak silat activities. This happens through experience and learning when participating in pencak silat activities. Such as being able to socialize, respecting parents/adults more, being sensitive to the environment, and having a more mature personality.
\end{abstract}

Keyword: Self-control, martial arts, youth, emotional intelligence.

\begin{abstract}
Abstrak
Tujuan penelitian ini yang pertama, untuk mengetahui bentuk pengendalian diri pada pencak silat. Kedua, untuk mengetahui bentuk peningkatan pengendalian diri siswa MTsN 6 Ponorogo. Adapun rumusan masalah dalam penelitian ini yang pertama, bagaimana pengendalian diri remaja yang mengikuti kegiatan pencak silat. Kedua, Bagaimana bentuk- bentuk peningkatan pengendalian diri remaja melalui kegiatan pencak silat di MTsN 6 Ponorogo. Untuk menjawab permasalahan terebut, penelitian ini menggunakan jenis penelitian yang bersifat deskripsi dengan pendekatan
\end{abstract}


kualitatif. Peneliti mendapatkan data dari wawancara, observasi dan dokumentasi. Hasil penelitian menunjukan bahwa bentuk peningkatan pengendalian diri siswa MTsN 6 Ponorogo sesuai dengan teori yang dipaparkan peneliti. Pertama, mampu mengendalikan emosi. Kedua, Mampu beradaptasi, penyesuaian ini dapat berarti mengubah diri pribadi sesuai dengan keadaan lingkungan. Siswa yang mengikuti pencak silat dapat menyesuaikan diri dimana ia berada. Ketiga, Prestasi yang didapatkan pada pencak silat akan mengembangkan kreativitas siswa. Melalui permasalahan yang dihadapi otomatis akan membuat siswa berfikir untuk menemukan jalan keluarnya. Kreativitas siswa akan membuat suasana menjadi nyaman dan kondusif. Terjadi peningkatan pengendalian diri pada siswa yang mengikuti kegiatan pencak silat. Hal ini terjadi melalui pengalaman dan pembelajaran ketika mengikuti kegiatan pencak silat. Seperti mampu bersosialisai, lebih menghormati orang tua/orang dewasa, peka terhadap lingkungan, dan memiliki kepribadian yang lebih dewasa.

Kata kunci: Pengendalian diri, pencak silat, remaja, kecerdasan emosi.

\section{PENDAHULUAN}

Pengendalian diri merupakan kontrol diri terhadap kejadian yang telah dialami secara langsung dan tidak langsung. Pengendaian diri secara langsung biasanya terjadi pada apa yang dilihat dan apa yang dirasakan. Sedangkan secara tidak langsung bisa melalui kabar dari orang lain, sosial media, dan berbagai informai dari manapun ${ }^{1}$. Banyak bentuk sikap pengendalian diri yang terjadi ketika mengalami suatu kejadian seperti marah, ada yang menangis, ada yang histeris bahkan ada pula yang pingsan ${ }^{2}$. Maka dari itu pengendalian diri dinilai sangat penting bagi kehidupan dan bermasyarakat.

Meningkatkan pengendalian diri bisa didapatkan dimanapun. Bisa di sekolah, lingkungan, dan teman sepergaulan. Kurangnya pengendalian diri juga bahaya bagi seseorang. Ketika seseorang mengalami sebuah kejadian tanpa bisa mengendalikan dirinya dengan baik maka hal yang tidak diinginkan pun bisa terjadi. Meningkatkan pengendalian diri melalui sekolah sudah hal wajar yang diberikan guru kepada muridnya. Tujuan dari pendidikan yaitu untuk berkembangnya poteni siswa menjadi orang yang beriman dan bertaqwa kepada Tuhan yang maha esa,

\footnotetext{
${ }^{1}$ A. Idris, "Hubungan Antara Pengendalian Diri Dan Religiusitas Dengan Perilaku Seks Bebas Remaja" 3, no. 1 (2018).

${ }^{2}$ M.A. Magsan, "Membangun Kontrol Diri Remaja Melalui Pendekatan Islam Dan Neuroscience," Psikologika 22, no. 1 (2017).
} 
berakhlak mulia, berilmu, kreatif, mandiri dan dapat bertanggung jawab ${ }^{3}$. Terlepas dari semua itu tujuan pendidikan juga dapat mewujudkan proses pembelajaran siswa yang aktif sehingga akan mengembangkan potensi siswa memiliki kekuatan spiritual agama, pengendalian diri yang berkembang, berkepribadian yang baik, kecerdasan, dan penanaman nilai-nilai sikap dan perilaku para muridnya.

Proses pembelajaran seharusnya para guru dan pengajar dapat menanamkan nilai-nilai sikap dan perilaku positif kepada para siswa. Namun pada kenyataanya, guru hanya fokus pada tugasnya untuk mengajar, guru kurang peka terhadap perilaku siswa. Perilaku siswa dipengarui oleh lingkungan pergaulan dan teman sebaya. Tidak sedikit siswa yang mengembangkan perilku negatifnya disekolah. Disekolah siswa menunjukkan perilaku yang melangar norma. Oleh sebab itu banyak siswa yang mebolos sekolah, berkelahi, dan pembulian.

Sebuah fenomena kasus mengenai bullying terjadi salah satu SMP di butuh, Purworejo, Jawa Tengah. Tiga pelaku bullying telah diangkap polisi setelah vidio rekaman pelaku bullying menyebar luas disosial media. "sudah ditetapkan sebagai tersangka, “ kata kapolres Purworejo AKBP Rizal Marito saat di konfirmasi, kamis (12/2). Ketiganya disangkakan melanggar pasal 80 undang-undang perlindungan anak tentang kekerasan terhadap anak. Ancaman hukumannya adalah 3 tahun 6 bulan penjara. Menurut kepala Bidang Humas Polda Jateng Kombes Iskandar F. Sutiasna ketiga tersangka tersebut tidak ditahan meski telah ditetapkan sebagai tersangka. Meski tidak ditahan, Iskandar memastikan proses hukum terhadap ketiganya akan tetap berjalan. Rekaman vidio menunjukan perilaku bullying tiga siswa terlihat memukul salah satu siswi di SMP Butuh, Purworejo. Guberneur Jawa Tengah Ganjar Pranowo telah mengaku akun sosial media milik beliau banyak dibanjiri vidio kejadian di SMP Butuh. Dengan sigap Gubernur Jawa Tengah langsung menghubungi kepala sekolah dan bupati untuk mengurus kasus tersebut. Dan Ganjar Pranowo juga meminta pengawas sekolah dan dinas terkait untuk turun agar berbicara dengan tua anak-anak tersebut. Ganjar juga berpesan untuk selalu menyayangi temanmu.

Perilaku bullying sering terjadi pada siswa remaja SMP. Kerap sekali berita televisi menyiarkan tentang perilaku bullying. Perilaku bullying yang biasa

\footnotetext{
${ }^{3}$ M.N. Purwanto, Psikologi Pendidikan (Bandung: PT. Remaja Rosdakarya, 2004).
} 
dilakukan oleh siswa biasanya berupa memberikan julukan nama yang membuat korban merasa tidak nyaman, ejekan, penghinaan, intimidai, pemalakan, penganiayaan, dan pemalakan. Perilaku bullying dilakukan dengan sengaja yang diperngaruhi oleh beberapa faktor. Seperti faktor sosial, kebudayaan, dan ekonomi. Namun pada usia remaja banyak terjadi bullying dikarenakan salah satu pihak merasa dirinya lebih kuat dan kurangnya pengendalian diri. Maka dari itu pengendalian diri menjadi salah satu aspek terpenting yang harus dimiliki siswa remaja. Siswa seharusnya mengetahui dan dapat membedakan perilaku yang dapat diterima maupun ditolak, namun perilaku yang ditolak masih tetap dilakukan karena gagal mengembangkan kontrol diri.

Mengembangkan pengendalian diri bisa dilakukan dengan mengikuti kegiatan yang bersifat positif. Salah satunya mengikuti kegiatan pencak silat. Kegiatan pencak silat biasanya dilaksanakan pada malam hari atau hari libur sekolah. Hal itu pastinya tidak akan mengganggu proses belajar wajib siswa remaja. Pada jaman sekarang banyak orang tua yang mendaftarkan anaknya untuk mengikuti kegitan pencak silat.

Pencak silat adalah suatu perbuatan manusia yang mengarahkan kekuatan jiwa dan raganya dalam rangka membela dirinya ${ }^{4}$. Dengan kata lain, pencak silat diciptakan untuk membela diri dari berbagai ancaman yang menyerangnya. Sebagai alat bela diri dimungkinkan seseorang mengerahkan potensi (kekuatan) yang ada semaksimal mungkin. Oleh karena itu dalam usaha pengabdian hasil budaya itu, pencak silat perlu dicatat dan digali. Pencak silat merupakan hasil budaya bangsa kita yang perlu ditingkatkan dan dikembangkan, karena bila hal itu terlambat maka kemungkinan pencak silat akan kehilangan peran dalam membangun identitas kepribadian bangsa ${ }^{5}$.

Olahraga pencak silat adalah warisan budaya leluhur dari negeri ini Indonesia, pencak silat sudah lama dikenal oleh masyarakat sejak jaman dahulu sebelum bangsa dan negara ini ada ${ }^{6}$. Pencak silat sudah menjadi bagian dari gaya hidup masyarakat pada saat itu. Setiap remaja pada masa itu harus mempunyai kemampuan dibidang

${ }^{4}$ E.S. Kriswantoro, Pencak Silat: Sejarah Dan Perkembangan Pencak Silat Teknik- Teknik Dalam Pencak Silat Pengetahuan Dasar Pertandingan Pencak Silat (Yogyakarta: Pustaka Baru, 2015).

${ }_{5}^{5}$ Mulyana, Pencak Silat Membangun Jati Diri Dan Karakter Bangsa (Bandung: PT. Remaja Rosdakarya, 2014).

${ }^{6}$ A. Trilaksana, "Perkembangan Ikatan Pencak Silat Indonesia (IPSI) Tahun 1948-1973," Jurnal

Pendidikan Sejarah 6, no. 3 (2018). 
pencak silat minimal untuk membela diri. Pada zaman sekarang konteks sudah berbeda, pencak silat tidak hanya sebagai gaya hidup, tetapi juga sebagai alat pemersatu bangsa dan juga sebagai alat untuk mengharumkan nama bangsa dikancah internasional.

Mengikuti kegiatan pencak silat juga dapat melatih mental dan fisik seseorang. Manfaat melatih mental akan menimbulkan seseorang memiliki mental yang kuat, hal itu ditunjukan dengan berani berbicara didepan banyak orang, mampu menyampaikan ide dan gagasan, dan menghadapi masalah dengan tenang dan bertanggung jawab. Sedangkan hasil dari pelatihan fisik tubuh akan menjadi sehat dan bugar. Pelatihan fisik juga akan mengembangkan otot-otot pada tubuh dengan dapat melakukan sebuah kegiatan yang berhubungan dengan tenaga.

\section{METODE PENELITIAN}

Untuk membantu dan menunjang penelitian ini, metode yang digunakan yaitu studi lapangan dengan cara melakukan survei langsung ke lokasi penelitian untuk mendapatkan informasi pegendalian diri remaja melalui kegiatan pencak silat ${ }^{7}$. Adapun tahapan penelitian sebagai berikut:

a. Melihat fenomena

Melihat fenomena banyaknya para remaja sekarang mengikuti kegiatan pencak silat dengan tujuan yang berbeda-beda. Hal ini menarik untuk dilakukan penelitian tentang peningkatan pengendalian diri remaja yang mengikuti kegiatan pencak silat. Langkah selanjutnya adalah menulis proposal penelitian. Ini dimaksudkan untuk memberikan gambaran atau deskripsi tentang rencana kegiatan penelitian dilokasi penelitian secara lengkap, jelas, singkat, dan mudah dipahami sebagai pertimbangan bagi pihak yang memberikan persetujuan atas kegiatan penelitian yang dilakukan.

b. Melakukan penelitan

Langkah ini merupakan inti dari kegiatan penelitian yang akan dilakukan. Yang bertjuan untuk memperoleh, dan menganalisa data yang telah diperoleh dari tujuan lapangan untuk penelitian.

c. Melakukan penulisan laporan

\footnotetext{
${ }^{7}$ Basrowi; Suwandi, Memahami Penelitian Kualitatif (Jakarta: PT. Rineka Cipta, 2008).
} 
Penulisan laporan adalah tahap akhir dari dari proses pelaksanaan penelitian. Setelah semua komponen-komponen terkait dengan data dan hasil analisa data serta mencapai suatu kesimpulan, peneliti mulai menulis laporan dalam konteks laporan kualitatif. Penulisan laporan disesuaikan dengan metode dalam penulisan penelitian kualitatif dengan tidak mengabaikan kebutuhan penliti terkait dengan kelengkapan data.

\section{HASIL PENELITIAN DAN PEMBAHASAN.}

Meningkatkan pengendalian diri bisa dimulai sejak remaja. Pengendalian diri sangat diperlukan dalam kehidupan sehari-hari. Hal ini disebabkan karena dalam kehidupan sehari- hari, remaja sering kali menghadapi masalah dari luar mapun dalam diri sendiri ${ }^{8}$. Dengan demikian pengendalian diri yang baik akan dapat menyelesaikan masalah yang sedang dihadapi. Untuk itu, para remaja perlu meningkatkan pengendalian diri. Meningkatkan pengendalian diri bisa didapatkan dimana saja, sepeti di sekolah, di lingkungan rumah, pengalaman hidup, dan lainlain.

"Saya merasakan perbedaan menjadi lebih baik mas dari pada tahun yang lalu sebelum mengikuti pencak silat. Ketika proses latihan pencak silat ketika diejek saya merasakan sangat marah dan emosi. Rasanya ingin saya ajak berkelahi, karena saya mengkikuti pencak silat saya merasa mempunya fisik yang kuat. Tapi setelah selesai latihan saya biasa aja, saya anggap itu sebuah bercandaan sebuah teman yang $a k r a b "$

Pada hasil wawancara tersebut dapat terlihat adanya perkembangan emosi menjadi lebih stabil. Perubahan tersebut juga berdampak dalam kehidupan seharihari, jika anggota benar-benar serius dan fokus dalam menjalani latihan maka akan tertanam pada diri anggota tersebut sifat-sifat yang baik dan emosi yang positif. Pada pelatihan pencak silat diajarkan bebrapa jenis kegiatan, seperti pemanasan, senam, jurus, dan sparing. Beberapa jenis kegiatan tersebut ternyata dapat dijadikan sebuah pelajaran mengelola emosi. Contohnya pelatih akan mengamati bagaimana perkembangan emosi seseorang ketika sparing/sambung. Sparing/sambung adalah

\footnotetext{
${ }^{8}$ M. Ndari, S.S.; Amelia, V. \& Khusianawati, Metode Perkembangan Sosial Anak Sejak Dini (Tasikmalaya: Edu Publisher, 2018).
} 
kegiatan untuk mempraktikan hasil latihan kepada sesama anggota dengan satu lawan satu. Kegiatan ini bertujuan untuk melihat perkembangan teknik dan emosi yang dipelajari selama proses pelatihan. Ketika terkena serangan apakah akan langsung membalas, atau akan menunggu sebuah kesempatan untuk membalas dengan tepat dan sesuai sasaran.

Dari pengalaman mengikuti pencak silat tersebut individu mampu untuk tidak terpengaruh emosi yang dirsakannya. Ketika individu merasakan sebuah emosi, mereka tetap bisa berfikir dengan baik dan melakukan sesuatu denga baik tanpa terpengaruh emosi tersebut. Berdasarkan proses siswa mengikuti kegiatan pencak silat, peneliti menyajikan pada hasil penelitian bahwa anggota tersebut sudah tidak terpengaruh emosinya. Anggota tersebut suddah mampu mengontrol emosinya dengan baik ketika dihadapkan dengan kegiatan yang dapat menimbulkan sebuah emosi namun ada beberapa anggota yang belum mampu megelola emosinya dengan baik karena masih baru dalam menjalani proses latihan tersebut.

Dalam teori regulasi emosi terdapat beberapa aspek yang membahas regulasi emosi, aspek-aspek tersebut yaitu: strategi emotion regulation (strategi regulasi emosi), engagin in goal directed behavior (terlibat dalam perilaku yang diarahkan pada tujuan, acceptance of emotional respons (penerimaan respon emosional). Yang dimaksudkan tersebut merupakan sebagai sebuah proses individu dalam mengatur emosinya dalam menghadapi masalah pada kehidupan sehari-hari baik melalui pendekatan kepada manusia ataupun pendekatan kepada Tuhan YME.

"biasa nya kalau awal baru mengikuti pencak silat suka igin menang sendiri mas seperti kemarok, arogan, nanti kalu sudah menjadi anggota terlihat berbeda akan terlihat dewasa. Sopan ada guru, apalagi kalau gurunya sama-sama oraganisasi pencak silat, dia akan lebih hormat dan sopan. Tapi sebenanrnya tu semua tergantung siswanya sendiri”bu M.M.

Menurut bu M.k sebuah pelatihan dapat menjadikannya menjadi lebih dewasa, namun itu semua akan mengalami proses untuk mencapai tujuan tersebut. maksudnya adalah ketika masih dalam proses mengikuti latihan anak belum mampu mengelola emosinya dengan baik, sehingga belum muncul perubahan dari emosi negatif menjadi emosi positif. Perubahan bisa dirasakan setelah selesainya mengikuti latihan pencak silat. Setelah selasainya proses mengikuti pencak silat anak akan 
merubah emosi negatif menjadi emosi positif. Seperti awalnya arogan menjadi lebih sopan, awal sombong menjadi lebih bisa menghargai orang lain. Dengan dimiliki pengendalian diri melalui pencak silat, dapat menahan gejolak emosinya.

Mekanisme perubahan yang terjadi pada anak karena menerapkan ajaran pencak silat yang diberikan. Anak akan menerima informasi dan akan masuk kedalam sebuah memoeri anak. Kemudian anak tersebut akan memproses informasi dengan sedikit usaha ataupun tanpa usaha. Setelah anak akan merespon melalui tindakan setelah terjdinya proses mengelola informsi tersebut.

Disisi lain dalam kehidupan sehari-hari, kita temukan juga manusia sebagai individu tetap dituntut pertanggung jawaban atas tindakan-tindakannya karena dianggap memiliki kehendak kebebasan yang memungkinkan untuk memiliki lebih banyak pilihan.

Model Lewin mengilustrasikan pengaruh kekuatan baik yang mendorong atau menghambat perubahan. Dalam hal ini, faktor penggerak yang akan mendorong perubahan secara positif, sedangkan faktor penghambat akan menahan perubahan kembali kepada status yang berlaku sebelumnya. Dengan demikian, perubahan akan terjadi ketika faktor penggerak lebih besar dibandingkan dengan faktor penghammbat.

Proses pelatihan pencak silat ini merupakan tahapan penyesuaian dari nilainilai yang baru untuk berlaku pada pesertanya. Tujuan utama dari tahap ini adalah untuk menstabilkan hal yang baru yang dihasilkan dari perubahan dengan menyeimbangkan faktor penggerak dan faktor penghambat.

"Ada anak bernama F.R contoh perubahan emosinya yang kurang. Faro mempunyai kepercaayaan diri yang bagus, sopan santun yang bagus, sama pelatihnya juga sangat menghormati tapi mentalnya kurang bagus. Seperti ketika dimarahi dibentak pasti akan nangis. Namun itu semua bukan dari faktor latihan saja, namun ada faktor-faktor lain yang mempengaruhi perkembangan emosi anak, bisa dari lingkungan rumah, lingkungan sebaya dan lain-lain”

Banyak faktor yang mempengaruhi perkembangan emosi anak. Faktor tersebut bisa dari anak itu sendiri, lingkungan, teman, dan pola asuh orang tua. Faktor tersebut akann terekam ke memori anak kemudian akan dijadikannya sebuah pengalaman dalam kehidupan sehari-hari. Perkembangan otak anak akan berubah 
jika orang tua membantu mengatasinya. Emosi seseorang yang mudah terangsang dapat dijinakkan melalui pengalaman-pengalaman yang diperoleh melalui pelajaran dan respon emosional yang dipelajari anak sewaktu ia tumbuh. Orang tua yang setahap demi setahap memberikan pengalaman yang membesarkan hati anak akan mampu membuat anak mampu mengurangi rasa takutnya.

Menurut Goleman", pelajaran emosi yang diberikan orang tua pada anak memiliki pengaruh besar terhadap tempramen anak, baik meredam atau memperbesar tempramen lainnya. Pembelajaran emosi ini bukan hanya hal-hal yang dicuapkan orang tua kepada anak, melainkan juga melalui contoh-contoh yang mereka berikan sewaktu menangani perasaan mereka sendiri. Orangtua yang tidak matang dalam emosinya ketika sedang depresi atau menghadapi masalah, akan kemungkinan kecil memberikan perhatian yang memadai kepada anaknya. Orang tua yang emosninya terganggu, mengalami stres atau depresi lebih besar kemungkinan akan menjadi dingin dan tidak tanggap pada kebutuhan emosonal anaknya. Interaksi emosional orang tua dengan anakknya akan berpengaruh besar pada masa depan anak karena dengan membuat ikatan-ikatan emosonal yang kuat dengan anak berarti anak mengembangkan kemampuan emosionalnya.

Selain mengelola emosi, data yang didapatkan di lapangan adalah adaptasi seorang siswa yang mengikuti kegiatan pencak silat. Dalam pembahasan pengendalian diri remaja yang mengikuti kegiatan pencak silat siswa MTsN 6 Ponorogo menunjukan tanda-tanda bahwa siswa tersebut mampu beradaptasi dengan baik. hasil itu dapat dilihat melalui sebuah wawancara dengan guru MTsN 6 Ponorogo.

"Selama itu semua tidak mengganggu pelajaran atau kegiatan ya silahkan-silahkan saja. Bahkan pihak sekoah memberikan dispensasi kepada siswa yang berkepentingan dengan pencak silat asal ada surat resminya".

Menurut keterangan dari pak A.N walaupun siswa mengikuti kegiatan pencak silat diluar jam sekolah namun itu tidak mengganggu proses kegiatan belajar disekolah. Disini siswa dapat beradaptasi dengan membagi waktu antara kegiatan sekolah dan kegiatan pencak silat. Namun apabila siswa mempunyai kesibukan pad pencak silat dan menyita waktu kegiatan sekolah pihak sekolah pun juga tidak

\footnotetext{
${ }^{9}$ D. Goleman, Kecerdasan Emosional (Jakarta: Gramedia Pustaka Utama, 1999).
} 
keberatan memberikan dispensasi. Seperti kegiatan pengesahaan yang paling tidak membutuhkan waktu dua hari. Denga adanya alasan yang tepat dan ada juga surat resmi dari pihak pencak silat, pihak sekolah akan memberikan dispensasi.

Indikator seseorang yang mampu beradaptasi dengan baik antara lain, mampu Memenuhi berbagai kebutuhan, perubahan prioritas, dan segala macam perubahan. Bersiap diri menerima dan menyesuakan dengan keadaan. Salah sau indikator tersebut telah terpenuhi sebagai siswa yang mengikuti pencak silat siap menerima dan menyesuaikan keadaan. Dengan mengikuti kegiatan pencak silat, pastinya seorang siswa akan mengalami kelelahan, dan rasa ngantuk di pagi hari. Karena kebanyakan kegiatan pencak silat dilakukan pada malam hari.

Adaptasi adalah suatu penyesuai pribadi terhadap lngkungan, penyesuaian ini dapat berarti megubah diri pribadi sesuai dengan keadaan lingkungan. Adaptasi berupa penyesuaian bentuk tubuh, penyesuaian tingkah laku, dan penyesuaian fungsi tubuh. Cara yang digunakan untuk beradaptasi setiap makhuk hidup berbeda sesuai dengan kemampuan individu tersebut. Misalkan pada tumbuhan digurun pasir, maka tanaman kaktus akan bisa bertahan karena mampu beradaptasi dengan lingkungan yang kekurangan air dengan keadaan daun seperti jarum.

Bukan hanya disekolahan, siswa diharapkan dapat beradaptasi dilingkungan dan teman nya. Kemampuan beradapatasi akan mensukseskan diri di masa mendatang. Dimana setelah bekerja kemampuan beradaptasi dengan hal baru sangat dibutuhkan untuk bertahan hidup. Kemampuan ini dibutuhkan juga untuk dapat berkomunikasi dengan baik terhadap lingkungan dimana berada.

Hal ini sesuai yang didapatkan dilapangan perubahan yang terjadi pada anak dapat berkomunikasi dengan baik dengan orang tuanya. Yang dimaksudkan berkomunikasi dengan baik disini seorang anak mampu bersopan santun terhadap orang tua atau umur yang diatasnya. Terjalinnya komunikasi yang baik juga akan meminimalisir kesalah pahaman kemudian akan terciptanya sebuah kehidupan yang harrmonis.

Komunikasi sendiri adalah proses penyampian pesan melalui pesan verbal maupun nonverbal. Verbal adalah penyampaian pesan dengan lisan sedangkan nonverbal adalah penyampaian pesan menggunakan bahasa isyarat atau gerakan tubuh. Ditinjau dari hasil peneltian didapatkan data siswa yang mengikuti 
kegiatan pencak silat juga mendapatkan sebuah prestasi. Dalam keikutsertaan porseni, MTsN 6 Ponorogo mendapat presatsi dalam cabang olahraga pencak silat. Pada cabang olahraga pencak silat, MTsN Ponorogo mampu mendapakan juara umum. Untuk puutri berhasil memperoleh juara kedua seni regu, sedangkan untuk tunggal juga mendapatkan juara 2. Sedangkan putra hanya mendapat juara ke tiga seni tunggal.

"Tahun kemarin siswa dari medang juara seni tunggal di ajang porseni mas, hal tersebut sangat di apresiasi pihak madrasah. Untuk tahuntahun berikunya pihak madrasah akan mengikut sertakan event pencak silat. Dilihat kalau siswa mempunyai potensi maka akan kita bina dan akan diikut sertakan"

Sesuai hasil data dilapangan siswa mampu mendapatkan prestasi pada ajang pencak silat ketika ia bersungguh-sungguh dan dalam proses menjalani pelatihan. Dalam prestasi ini siswa mendapatkan hasil apa yang ia tekuni dan apa yang jalani dengan serius. Prestasi adalah hasil dari apa yang telah dicapai dari suatu usaha yang telah dikerjakan dan diciptakan baik secara individu maupun kelompok. Prestasi tersebut biasanya didapatkan melalui even atau ajang perlombaan. Sedangkan pada hasil penelelitian ini prestasi didapatkan setelah mengiktui Porseni.

Dalam sebuah ajang perlombaan selain prestasi kreatifitas siswa juga akan berkembang. Melalui sebuah permasalahn dalam perlombaan otomatis para peserta akan berfikir bagaimana caranya untuk menang. Dari hasil pemikiran itu pula akan terjadinya sebuh keatifitas untuk mencapai tujuan tertentu.

\section{PENUTUP}

Berdasarkan penelitian dalam skripsi "Peningkatan Pengendalian Diri Remaja Melalui Kegiatan Pencak Silat Siswa MTsN 6 Ponorogo" dapat diambil kesimpulan yaitu:

1. Pengendalian diri remaja pada pencak silat

a. Mengelola emosi

Siswa siswi yang mengkuti pencak silat dapat mengelola emosi dengan penanaman yang telah diajarkan pada pencak silat. Pengalaman mengikuti pencak silat akan membuat siswa lebih bisa mengendelakian emosinya. Dengan dimiliki pengendalian diri melalui kegiatan pencak silat siswa juag 
dapat menahan gejolak emosinya. Perubahan emosi yang terjadi pada anggota perguruan pencak silat ini akan terlihat seiring dengan kesungguhan mereka menjalani proses latihan. Dengan latihan yang disiplin dan terus menerus, emosi negatif seperti mudah marah, malas dan kurang percaya diri bisa diatasi dengan bertahap.

b. Beradaptasi

Mampu beradaptasi, penyesuaian ini dapat berarti mengubah diri pribadi sesuai dengan keadaan lingkungan. Siswa yang mengikuti pencak silat dapat menyesuaikan diri dimana ia berada. Penyesuaian diri bisa dengan menyesuaikan tempat, menyesuaikan waktu, dan menyesuaiakn diri dengan siapa ia berkomunikasi

c. Prestasi

Prestasi yang didapatkan pada pencak silat akan mengembangkan kreatiftas siswa. Melalui permasalahan yang dihadapi otomatis akan membuat siswa berfikir untuk menemukan jalan keluarnya. Kreativitas siswa akan membuat suasana menjadi nyaman dan kondusif.

2. Bentuk peningkatan pengenadalian diri melalui kegiatan pencak silat

Terjadi peningkatan pengendalian diri pada siswa yang mengikuti kegiatan pencak silat. Hal ini terjadi melalui pengalaman dan pembelajaran ketika mengikuti kegiatan pencak silat. Seperti mampu bersosialisai, lebih menghormati orang tua/orang dewasa, peka terhadap lingkungan, dan memiliki kepribadian yang lebih dewasa.

\section{DAFTAR RUJUKAN}

Basrowi; Suwandi. Memahami Penelitian Kualitatif. Jakarta: PT. Rineka Cipta, 2008.

Goleman, D. Kecerdasan Emosional. Jakarta: Gramedia Pustaka Utama, 1999.

Idris, A. "Hubungan Antara Pengendalian Diri Dan Religiusitas Dengan Perilaku Seks Bebas Remaja" 3, no. 1 (2018).

Kriswantoro, E.S. Pencak Silat: Sejarah Dan Perkembangan Pencak Silat TeknikTeknik Dalam Pencak Silat Pengetahuan Dasar Pertandingan Pencak Silat. Yogyakarta: Pustaka Baru, 2015. 
Magsan, M.A. "Membangun Kontrol Diri Remaja Melalui Pendekatan Islam Dan Neuroscience.” Psikologika 22, no. 1 (2017).

Mulyana. Pencak Silat Membangun Jati Diri Dan Karakter Bangsa. Bandung: PT. Remaja Rosdakarya, 2014.

Ndari, S.S.; Amelia, V. \& Khusianawati, M. Metode Perkembangan Sosial Anak Sejak Dini. Tasikmalaya: Edu Publisher, 2018.

Purwanto, M.N. Psikologi Pendidikan. Bandung: PT. Remaja Rosdakarya, 2004.

Trilaksana, A. "Perkembangan Ikatan Pencak Silat Indonesia (IPSI) Tahun 19481973." Jurnal Pendidikan Sejarah 6, no. 3 (2018). 